\title{
DAMOPHON.
}

Mr. A. M. Daniel's article on the above subject (pp. 41 seq.) is so thorough and convincing that it hardly requires further support. But in view of the widespread acceptance of the attribution of the Lycosura statues to a late Roman date, I think a few words in further confirmation of his contention are not out of place.

In spite of the almost unanimous volte-face in the opinion of archaeologists since Dr. Doerpfeld expressed his doubts as to the Greek character of the buildings at Lycosura, my own view (expressed in the Athenaeum, March 22nd, 1890, and at a public meeting of the American School at Athens, January 6th, 1891) that Damophon's work belongs to the first half of the fourth century B.C. has not been shaken. Of course we must all remember that we have here to deal with the question of probability and not of certainty. Yet within these limits it appears to me that the balance of evidence strongly inclines towards the fourth century B.C.

There is little to add to Mr. Daniel's excellent analysis and comparison of style. Taking merely the treatment of the eyes and brow and the lids in these heads, the material which we have at our disposal, now, would make it almost certain that they could not have been worked later than the fourth century; they certainly do not manifest the characteristic treatment which we find in the second century B.C., or in Hadrianic work. If, moreover, we remember the choice of subjects which this sculptor makes (a point, to my mind, of extreme importance in judging the date of a Greek artist), and if we note how he chooses almost exclusively gods, among whom Asclepius is foremost, remembering further that Asclepius seems to have come into such prominence in the first half of the fourth century, we shall find it hard on these grounds to believe that Damophon is a sculptor of the second century B.c. or of the Hadrianic period.

Another peculiarity of technical treatment seems to me most significant: though the eyebrows and eyelids are treated in the same manner in all three heads, the orb itself is completely worked in the head of Demeter; while in those of Anytus and Artemis it is hollowed out to receive the insertion of some foreign matter. The hair of Artemis is completely modelled in the marble, while that of Demeter was supplemented by the insertion of bronze ornaments. This uncertainty of technique, or rather, this searching after a fixed method for dealing with such statues, seems to me to find its best explanation in the hypothesis that the artist marks the transition from the 


\section{Important Notice.}

\section{THE}

\section{SOCIETY FOR THE PROMOTION OF HELLENIC STUDIES.}

Facsimile Reproduction of the Codex Venetus of Aristophanes.

THE photographic facsimile of this important 1 MS. was undertaken jointly by the Archæological Institute of America and the Society for the Promotion of Hellenic Studies, with the permission of the Government of His Majesty the King of Italy, and was issued to subscribers at the end of 1902 at a price which compares very favourably with that of most similar publications, viz., $£ 6$ in portfolio, and $£ 66 s$. bound in half-morocco. Two hundred copies were printed, and of these two-thirds have already been sold. It has now been decided to raise the price of the remainder, on and after April I, 1905, to $£ 7$ and $£ 77 s$. respectively. Orders received before that date will be executed at the original price.

The Codex Venetus Marcianus CCCCLXXIV ranks with the Codex Ravennas as one of the two most important manuscripts of Aristophanes now in 
existence. In age it is somewhat later than the Ravennas, belonging to the latter part of the IIth century; in text it is not inferior, though it contains only seven plays as against the eleven of its rival; while in respect of the scholia with which its margins are filled, it is very greatly superior. It is indeed especially on account of the scholia that a reproduction was called for; for while the scholia of the Ravennas, though less valuable, have been edited in full, those of the Venetus, which are of prime importance for the criticism of Aristophanes, have never been adequately published. Since the appearance of this volume, the Codex Ravennas has also been published in facsimile by Mr. Sijthoff of Leiden at the price of $£ \mathrm{I} 2$; and thus the most important materials for the text of the great comic dramatist have been placed beyond the reach of destruction.

The plates, 344 in number, have been executed by the collotype process by the Oxford University Press from negatives taken by Mr. Bertani of Venice. A full palæographical introduction by Mr. T. W. Allen, Fellow of Queen's College, Oxford, is prefixed to the facsimile.

\section{(An Order Form is appended.)}

LONDON.

November, 1904. 


\section{ORDER FORM.}

Available only up to April I, I905.

GEORGE A. MACMILLAN, Es Q.,

Hon. Secretary.

Society for Promotion of Hellenic Studies,

St, Martin's Street, London, W.C.

Please send me cop of the Photographic Facsimile of the CODEX VENETUS of Aristophanes, issued by the American Archeological Institute and the Hellenic Society, at the original subscription price of f6:0 per copy. ${ }^{*} \quad I$ enclose remittance f6:6, , , for the amount.

Name

Address

Date

* Please strike out the style not required. 
gold and ivory or bronze technique in temple statues of the Phidian period to the pure marble technique of the age of Scopas and Praxiteles. And this hypothesis gains in probability when we remember the fact, upon which Brunn long ago laid stress, that Damophon, to whom 'honours are paid by the Eleans, fitted together with the utmost accuracy the image of Zeus at Olympia when the ivory in that image had cracked' (Pausanias, iv. 31.6). He thus bears a distinct relation to the gold and ivory technique of the fifth century, while, on the other hand, he himself uses the acrolithic technique (marble and gilt wood) and finally marble alone. This succession in the use of materials points to the first half of the fourth century B.c. and not to the Roman period.

But the strongest argument in favour of the earlier date of this artist is derived from the fact that his chief works were to be found at Megalopolis and Messene, which were both founded, or refounded, by Epaminondas about the year 369 B.C. 1 Now Megalopolis went under after the Macedonian period, and it is equally unlikely that Messene should in later ages have been in a condition to order as many works by Damophon as Pausanias thinks fit to mention. In the enumeration which Pausanias makes (ibid.) of the statues by Damophon at Messene he mentions the image of the city of Thebes and the statue of Epaminondas; and though he goes on to say that 'the marble images are the works of Damophon...... the statue of Epaminondas is of iron and is the work of some other artist,' the statue of Thebes remains for Damophon; and from the context it is unlikely that centuries elapsed between the creation of the other works and of the statue of Epaminondas. Thus the Theban supremacy under Epaminondas is distinctly indicated as the period when Damophon lived. Had I space, I should like to enlarge upon the probability, for which there is strong evidence, that this Theban supremacy coincided with the predominance of such mythological figures as Asclepius and Artemis, which hold so large a proportion among the statues marle by Damophon.

Charles Waldstein.

\footnotetext{
1 For the foundation of Megalopolis, see Niese, Hermes, 1899, Beiträge zur Gesch. Arkadiens, pp. $527 \mathrm{seq}$. See also Bury, J.H.S. 1898, pp. $15 \mathrm{seq}$.
} 